DOI: http://doi.org/10.4038/ss.v48i2.4712

\title{
Effect of Exchange Rate Volatility on Sri Lanka's Inbound Tourist Flow
}

Gayani Ishara Rathnayake ${ }^{1}$

\begin{abstract}
This paper investigates effects of exchange rate volatility on Sri Lanka's inbound tourism using monthly data on tourist arrivals, exchange rate and other related variables from 1990 to 2016. An Exponential Generalized Autoregressive Conditional Heteroscedasticity (EGARCH) model is used to generate a measure of exchange rate volatility. This is then incorporated in a tourism demand model to test its impact on tourist flows into the country. The empirical methodology depends on the theory of cointegration and error correction representation. The results reveal that there are significant negative short run and long run effects of exchange rate volatility on tourist flows to Sri Lanka. Further, it suggests that the Sri Lankan tourism product is a luxury good, having high income elasticity. In addition, tourism related inflation has a significant negative impact on the growth in tourist arrivals in the short run. However, in the long run, a reduction in price sensitivity is observed. Moreover, results highlight the significant positive impact of habit persistence or/ and word of mouth recommendation in increasing tourist flows to Sri Lanka. It further reveals the importance of maintaining a conducive economic, political and social environment to increase the demand for Sri Lankan tourism.
\end{abstract}

Key Words: Exchange rate Volatility, Tourism Demand, Cointegration, Error Correction, EGARCH model, Sri Lanka

JEL Classification: C32; F41; L83

\footnotetext{
${ }^{1}$ The author currently serves as a Senior Assistant Director of the Statistics Department at the Central Bank of Sri Lanka. Corresponding email: gayani_ishara@cbsl..lk. The views presented in this paper are those of the author and do not necessarily indicate the views of the Central Bank of Sri Lanka.
} 


\section{Introduction}

The year 2017 has been designated as the' International Year of Sustainable Tourism for Development' by the United Nations and it focuses on promoting the role of tourism in five key sectors, namely "inclusive and sustainable economic growth", "social inclusiveness, employment and poverty reduction", "resource efficiency, environmental protection and climate change", "cultural values, diversity and heritage", and "mutual understanding, peace and security" (United Nations World Tourism Organization (UNWTO) International year for sustainable tourism). This highlights the significance of the tourism industry, throughout the world, in promoting sustainable economic growth. According to the World Travel and Tourism Council (WTTC) the total contribution of travel and tourism to global GDP was estimated at $10.2 \%$ in 2016 , while it accounted for $6.6 \%$ of total exports, generating one in ten jobs across the world (qtd. in UNWTO Tourism highlights 2016). In 2016, international tourist arrivals around the world recorded a robust growth rate of 3.9\%, reaching 1,235 million tourist arrivals (UNWTO Tourism highlights 2010). Thus, reflecting the high growth potential in this sector, the 2030 vision of the UNW'TO expects tourist arrivals to record a growth rate of $3.3 \%$ per year from 2010 to 2030 and reach 1.8 billion tourist arrivals by 2030. Accordingly, to capitalise on this growth potential many new tourist attraction destinations are adding in to this industry, increasing its competition.

In Sri Lanka, the tourism industry earned US dollars 3,518 million during 2016, recording a year on year growth rate of $18.0 \%$ (Central Bank of Sri Lanka (CBSL) Annual Report 2016). It plays a prominent role in the Sri Lankan economy through generating direct and indirect employment. In 2016, total estimated employment in the tourism industry was 335,659 (CBSL Annual Report 2010). Thus, developing the tourism sector is identified as one of the poverty reduction strategies. Sri Lankan tourism has been experiencing rapid growth and diversification especially in the post conflict era, achieving over 2 million tourist arrivals in 2016 when compared to 448,000 in 2009 (CBSL Annual Report 2010). According to the Ministry of Economic Development the target by 2020 is to achieve four million tourist arrivals along with US dollars 8 billion earnings, while generating one million employment opportunities (Ministry of economic Development Tourism Development strategy). Thus, authorities should develop policies to promote sustainable growth in this sector in order to achieve these targets. Therefore, when designing such policies, a clear understanding of the effect of exchange rate fluctuations on tourist flows into Sri Lanka is necessary together with an assessment of the impact of other tourism demand determinants. However, the effect of exchange rate volatility on Sri Lanka's inbound tourism (i.e. tourist flows to Sri Lanka) has not been adequately explored, highlighting a research gap, which lead to the research problem of this study.

According to the UNW'TO, a visitor (domestic, inbound or outbound) is classified as a tourist (or overnight visitor) if his/her trip includes an overnight stay (UNWTO International 
recommendations for tourism statistics). An Inbound tourist is defined as a foreigner or in other words a non-resident who visit a given country.

The exchange rate is formally defined as the number of units of one currency that can be exchanged for a unit of another (CBSL Exchange Rate). The nominal appreciation of an exchange rate is defined as a situation where the value of domestic currency increases with respect to a foreign currency and depreciation refers to the opposite relationship where the value of the domestic currency decreases with respect to a foreign currency. The exchange rate can be defined as either a nominal rate or a a real rate, where the real exchange rate is the nominal exchange rate adjusted to the purchasing power. Exchange rate regime refers to the method by which a country manages its exchange rate with respect to other countries around the world. There are two main exchange rate regimes found in literature, namely, the floating exchange rate regime and the fixed exchange rate regime, and there are intermediate exchange rates that lie between these two extremes. Most of the countries adopted the floating exchange rate regime after the breakdown of Bretton Woods agreement in 1973 and with this shift the impact of exchange rate volatility on international trade patterns has been a focal point of both theoretical and empirical investigators (Ozturk and Kalyoncu 499-513). In the current context, Sri Lanka follows an independently floating exchange rate regime (CBSL Exchange Rate).

Ozturk defined exchange rate volatility as the risk associated with unexpected movements in the exchange rate (Ozturk 85). However, the volatile exchange rate cannot be predicted with substantial accuracy since it indicates irregular changes. Furthermore, the association between tourism demand and exchange rate volatility is ambiguous. However, majority of empirical literature state that exchange rate volatility impacts tourist flows negatively since the choice of destination of risk averse tourists as well as travel agents is affected by the volatility of the exchange rate as they link it with uncertainty in social, political and economic environment in the destination country as well as it increases the transaction cost associated(Webber, 398405). For instance, Webber revealed that $40 \%$ of the sample under his investigation changed the decision to visit a destination due to fluctuations observed in the exchange rate. In addition, tour operators will consider other competitive destinations to avoid markets that are prone to unusual exchange rate fluctuations since they consider it as a business portfolio risk. The UNWTO also highlights the fact that unusually strong exchange rate fluctuation is one of the three key factors that influenced tourism flows in 2015 (UNWTO Tourism bighlights 2016). This further highlights the significance of assessing the relationship between tourist flows into a country and exchange rate volatility.

With the conclusion of the approximately thirty years long civil war, Sri Lanka is recently experiencing a high growth in both foreign and domestic tourism. In the post conflict era, tourism is identified as a significant driver of economic growth in the country, where it became the third largest foreign income earner in 2015 (CBSL, Annual report 2016). According to the World Travel and Tourism Council (WTTC) statistics the Sri Lankan tourism sector's contribution to GDP and its employment generation capability remains high above the world 
and Asian averages, however, it lags behind its competitors (qtd. in CBSL, Annual report 2016). According to the statistics published by the WTO for the year 2014, Sri Lanka's share of world tourist arrivals was 0.13 per cent which was only 0.2 per cent of total earnings from tourism in the world (qtd. in CBSL, Annual report 2010)). This reflects the enormous potential of Sri Lankan tourism industry to thrive in the future as well as its ability in narrowing the balance of payment deficit of the country through earning foreign income. Even though, inbound tourism is an important sector to the Sri Lankan economy very little research has been conducted focusing on this segment. Quite a few have focused the on tourism sector in Sri Lanka (Fernando et al. 575-586; Konarasinghe 57-63; Lelwala and Gunaratne 50-59; Selvanathan 35-38; Welgamage 90-101). However, no study has attempted to identify the effect of exchange rate volatility on Sri Lanka's inbound tourism, a notable gap this research attempts to bridge.

\section{Literature review}

\subsection{Factors affecting tourism demand}

The income of the origin country, relative prices between destination and origin, exchange rate, and transportation costs are identified as key influencing factors or explanatory variables of tourism demand in empirical literature (Agiomirgianakis et al., "Iceland" 25-34; Cheng 167181; Dogru et al. 47-55; Patsouratis et al. 1865-1870; Peng et al. 611-633; Song and Li .203220; Witt and Witt 447-475).

In most of the empirical research, tourism demand is measured by the number of tourist arrivals from an origin country to the foreign destination country (Song and Li, .203-220; Chu 1414-1420). Alternatively, certain studies employ tourism expenditure in the destination (Dogru et al. 47-55) as the proxy for tourism demand while others use tourism receipts (Akal 565-580) or expenditure of a particular product (Li et al. 57-71). These proxies are in line with theory, but different estimates may result depending on the proxy employed. However, Song et al. in their research concluded that tourism expenditure is a better proxy for demand than tourist arrivals (377-396). Nevertheless, it also depends on the objective of the research as well. Other indicators used, but rarely as a proxy for tourism demand, include tourist nights spent (Gouveia and Rodrigues 501 - 515), tourism employment (Witt, et al., 167 - 176) and length of stay (Gokovali, et al. 736-746).

\subsubsection{Income of the origin country as a tourism demand determinant}

Cheng based on his research concluded that international tourism is income elastic and thus is expected to be a luxury good in line with economic theory (167-181). Peng et al. further confirms this through a meta-analysis of studies published from 1960 to 2011, where the study revealed that the mean elasticity of tourism demand was 2.526 with a standard deviation of 3.065(611-633). This reflects that international tourism is in the "luxury" good category since income elasticity is greater than one in most of the empirical studies. Moreover, empirical 
literature considers Income as the most influential demand determinant of tourism (Crouch, "Review", 12-23). According to Crouch, estimated income elasticity differs with various income proxies ("Income" 643-669). Further, according to Peng et al. it differs with the destination-origin combinations considered (611-633).

The personal disposal income is the most ideal variable for measuring income, but this is not generally available (Gonzalez and Moral 233-251). Thus, empirical literature frequently uses real or nominal per capita Gross Domestic Product (GDP), Gross National Income (GNI), private consumption or personal disposable income as a proxy for income (Agiomirgianakis et al., "Iceland" 25-34; Patsouratis et al. 1865-1870; Peng et al. 611-633). However, Witt and Witt state that the most appropriate proxy depends on the type of tourist visit considered, for instance, if business visits are under consideration, then more general income variables such as GNI or GDP will be appropriate and if holiday visits are under consideration, then a measure such as personal disposable income or private consumption will be appropriate (447-475). Industrial Production Index (IPI) is also used as an alternative measure (Gonzalez and Moral 233-251; Mwangi et al. 1-12) when considering monthly data, since the highest frequency of reporting GNI or GDP is quarterly or annual in some instances. Dogru et al. in their study investigated the adequacy of IPI and conclude that it is not adequate as an income proxy as it only reflects industrial developments and omits service-related growth (47-55). However, they state that IPI can be beneficial in dealing with high frequency monthly data, which may contain in depth information and they also state that the adequacy will also depend on the country specific characteristics and modelling technique employed.

\subsubsection{Relative prices as a tourism demand determinant}

Literature reveals that relative prices is also an important factor impacting the tourism demand (Lim "Determinants" 447-485, "Analytic Review" 273-284). Dwyer and Forsyth state that when considering the tourism price factor, it includes two main elements namely, cost of transport to and from destination and cost of living for tourist at destination (751-777). The most frequently used proxy for relative prices is the ratio of Consumer Price Index (CPI) between destination country and origin country adjusted to exchange rates (Falk 101-112). This assumes that the major determinant for the decision of foreign travel is whether to spend the holiday at a particular destination or at the origin or in other words in the home country. Further, prices paid will be influenced by the prevailing exchange rate (Dwyer and Forsyth 751-777). However, using CPI to compute a proxy for the relative price of tourism is at the centre of debate. Many researchers argue that the use of a CPI proxy has a major drawback as it does not reflect the products brought by, the tourist, since the basket of goods reflect the consumption pattern of an average household (Dwyer and Forsyth 751-777). Some researchers validate the use of CPI by assuming that the trend in prices of the basket of goods and services consumed by tourists have a tendency to move in line with general consumer prices. Nevertheless, Divisekera showed that this assumption does not hold in all cases (31- 
49). Moreover, CPI lacks consistency between countries in terms of coverage and weights, and it only measures the change in price level so that no information is provided on actual price levels. Thus, to overcome these limitations, certain researchers propose using alternative customised tourism price variables like hotel price indices (Narayan 193 - 206.), separate tourism price index, service price index or index of price competitiveness (Dwyer and Forsyth 751-777). However, these can only be compiled through extensive data collection and processing, and in some instances, country specific definitions and computational methodologies will be an issue in cross country comparisons. Therefore, as highlighted by Pastorates et al. researchers continue to use CPI given the lack of data availability and timeliness of appropriate tourist specific price estimates (1865-1870). Witt and Witt state that any price measure that is used should be adjusted by the exchange rate to transform it to the currency of the origin country (447-475).

According to economic theory, the rise in price level results in a reduced demand for most of the goods and services (Crouch, "Review" 12-23; Crouch, "Survey" 41-55). Peng et al. in their "meta-analysis of International tourism demand elasticities" reveal that in empirical studies the estimated elasticity is negative, reflecting that increase in prices reduced tourist demand which is in line with economic theory (611-633). In particular, they found that overall average price elasticity to be -1.281 with a standard deviation of 1.818 . However, if "country(s) represented in the denominator complement tourism to the destination in question, or the income effect is strong, the opposite may occur" (Crouch, "Demand Elasticities" 117-136). Thus, both positive and negative elasticity is possible. For example, Agiomirgianakis, et al. in their research on the effects of exchange rate volatility on tourist flows to the United Kingdom (UK) and Sweden conclude that price relative is positive or in some cases insignificant for UK, implying that the destination selection of the tourist visiting $\mathrm{UK}$ is independent of the price factor and conclude that tourists visit UK for the unique tourist product it offers ("UK" 1-12 ). Dwyer and Forsyth state that with the high focus on destination differentiation strategies, the price sensitivity of the tourists has diminished over time (751-777).

Literature also reveals that the estimated price elasticity varies significantly depending on the origin- destination combinations considered. For example, Kraipornsak states that the international tourists coming to Thailand are highly sensitive to price where elasticity is estimated to be 3.0(93-108). In contrast, Schiff and Becken reveal that tourists visiting New Zealand from the UK, USA and Australia are not sensitive towards price levels where the price elasticity was estimated to be approximately -0.5(564-575). In addition, it is found that elasticity depends on the purpose of the trip. For instance, Crouch ("Effects of Income" 103-118) concludes that price elasticity is high in sun, sea and sand tourism compared to other types of tourism. Further, the Australian Bureau of Transport and Communications Economics finds that leisure travelers are more sensitive to price than business travelers. Apart from these factors, explanatory variables used, frequency of data, demand model used for modelling and 
proxy used influence the estimated price elasticity (Crouch, "Income" 643-669; Crouch," Demand Elasticities” 117-136; Lim” Determinants" 447-485).

\subsubsection{Exchange rate as a tourism demand determinant}

Use of exchange rate as a determinant in the tourism demand model is controversial. Empirical literature reveals that exchange rate appreciation at the destination will deter tourist flows to that destination country (Patsouratis et al. 1865-18705; Dwyer and Forsyth 751-777). Some researchers introduce the exchange rate as a separate factor since tourists are mindful of exchange rates than cost of living in the country visited and tour operators use exchange rate hedging (Patsouratis et al. 1865-1870), while others use the exchange rate only to standardise relative prices (Song and Witt, 214-224). In literature it is argued that since tourists are more aware about the exchange rate, they base their travel decisions on that Yap claims that exchange rate is a more representative measure of tourist's cost of living when compared to consumer price indices (111-132). However, exchange rate alone is not a satisfactory proxy for relative prices as favourable exchange rate may be a result of high inflation (Witt and Witt, 447-475). This is further confirmed by De Vita and Kyaw where they revealed that the exchange rate alone is not a significant factor effecting tourism demand, but relative prices adjusted by exchange rate is a significant factor (624-627). The studies that include an additional exchange rate variable apart from the price relative sometimes face issues such as multicollearity and modelling bias. For instance, Dogru et al. in their research revealed that there is an almost perfect negative correlation that is estimated to be 0.99 between exchange rate and relative prices standardized by the exchange rate (47-55). Thus, they concluded that including an exchange rate in addition to relative prices standardized by the exchange rate is undesirable and they recommended only using relative prices standardized by the exchange rate as a measure of tourist's cost of living at destination.

\subsubsection{Transport cost as a tourism demand determinant}

Airline ticket prices, travel distance and fuel cost are usually used to measure the transportation cost (Turner and Witt, 2001; Peng, et al., 611-633). Agiomirgianakis et al. ("Turkey" 700-725) state that cost of travelling to a specific country adversely impacts the tourist flow to that country but the study carried out by Lim (Lim "Determinants" 447-485) does not fully support this relationship. However, Witt and Witt states that due to the complexity of constructing a proxy with the available data and possible multicollinearity issues most of the researchers drop this factor from the tourism demand model (447-475).

\subsubsection{Other determinant considered in tourism demand models}

Other determinants considered include substitute prices of competitive destinations (Dogru et al. 47-55), trend and marketing expenditure (Crouch, "Survey" 41-55), dummy variables to capture the effects of seasonality (Agiomirgianakis et al., "Turkey" 700-725) as well as to 
capture the impact of special incidents (Song, et al. 63-81). Moreover, Peng, et al., identify variables such as foreign direct investment education level of tourists, destination promotional expenditure, immigration patterns and climate changes which are also occasionally used in tourism demand models (611-633).

\subsection{Relationship between tourist flows and volatility in the exchange rate}

Exchange rate volatility can be included as an additional variable in the tourism demand model to reflect the aspect of "uncertainty avoidance" when selecting the travel destination (De Vita and Kyaw 624-627).

Song and Witt state that the real exchange rate captures two effects of international tourism prices, which is the effect of nominal exchange rate as well as the impact of the relative prices. Further, they state that the association between the tourism demand and exchange rate volatility is expected to be negative as exchange rate volatility increase uncertainty as well as transaction cost associated with travelling abroad. This is further confirmed by Agiomirgianakisa, et al. in their research on "The Effects of Exchange Rate Volatility on Tourist Flows: Evidence from the UK and Sweden" where they reveal that for the UK there is a negative impact from exchange rate volatility on tourist arrivals indicating that tourist as well as travel agents respond to even small fluctuations in the exchange rate ("UK" 1-12). Further, they argue that for Sweden, exchange rate volatility of three per cent above or below the average has an adverse impact on potential tourists and travel agents. However, minor deviations in the exchange rate have no significant impact on tourist flows.

Agiomirgianakis et al. state that political or economic instability and social unrests in the destination country are also reflected through a volatile exchange rate apart from the changes in relative prices ("Turkey" 700-725). In this study, they find that there is a strong negative statistically significant effect of "exchange rate volatility" on tourist flows into Turkey. Further, they concluded that an increase in volatility reduces tourist arrivals more than proportionately, indicating that high volatility has a greater influence on the decision of tourists as well as tour operators whereas smaller changes have a lesser impact. This negative relationship among exchange rate volatility and tourism demand in Turkey is also confirmed by Aktaş and Özkan, where they use tourism revenue as a proxy for tourism demand (493-499). However, they concluded that the relationship is weak in the long run. Moreover, Agiomirgianakisa et al. revealed that this relationship holds for Iceland as well ("Iceland" 25-34). Saayman and Saayman in their study argue that exchange rate volatility significantly influences tourist expenditure and arrivals in South Africa (104-121). Peace et al. in their study find that a similar trend is observed in Nigeria where higher volatility decreases the contribution of the tourism industry to the national economy (48-55).

Webber in his study on analysing the long-run demand for Australian outbound leisure tourism for nine major tourism destinations shows that for a half of the countries under investigation, 
exchange rate volatility is a significant factor of long-run demand for tourism (398-405). Further, he highlights that since volatility in the exchange rate provides an indication on variations in relative price it influences the choice of travel destination. In contrast, Yap through his research claims that "a sudden appreciation of the Australian dollar will not have long term negative impact on tourist flows to Australia as tourist's memories of such shocks could lessen in the long run" (111-132).

This bidirectional relationship observed between number of tourists coming from a particular destination to a particular origin and bilateral exchange rate volatility is further investigated by Chang and McAleer in their research that focuses on investigating the impact of volatility in exchange rate on tourist arrivals to Taiwan from the world, USA and Japan, where they reveal the that impact of price and price volatility vary (397-419). Moreover, they claim that even though the exchange rate may have the expected negative impact on tourist arrivals, the effect of exchange rate volatility on tourist arrivals can have a positive or negative effect depending on the destination and origin pair considered.

Gallego, et al. in their research on exchange rate regimes and tourism find that an approximately $6.3 \%$ improvement in tourism is witnessed through the introduction of euro as a common currency. Further, they argue that intermediate exchange rate regimes such as managed floating or a currency peg also have an ability to promote tourism to a certain extent. Hence, they conclude that lesser the flexibility in exchange rate, higher the positive impact in promoting tourism. Ledesma-Rodríguez et al. (qtd. in De vita 223-236) also evaluate this trend for a sample of Organization for Economic Co-operation and Development (OECD) countries and concluded the same. Thompson and Thompson through their research further confirm this where they reveal that the introduction of euro increased tourist revenue by approximately 18\% in Greece (773-778). De vita in his study employing 27 OECD and nonOECD countries to identify the long-run impact of exchange rate regimes on international tourism flows reveals that there is a significant impact from multiple exchange rate regimes on tourism inflows to a particular country and emphasised that international tourists can be attracted through sustaining a stable exchange rate (223-236).

\subsection{Measuring exchange rate volatility}

Measuring the extent of the "exchange rate volatility" has become a concern for policymakers and academics mainly with the end of the Bretton Woods Agreement (Epaphra 121-143) where in 1973, foreign governments let currencies float (Investopedia, 2003). One of the main debates in empirical literature on this topic is whether to use real or nominal exchange rate in measuring volatility. Earlier studies have used nominal exchange rates (Thursby and Thursby, 488-495), while more recent studies have used real exchange rates (Peace, et al. 48-55; Agiomirgianakisa, et al. "Iceland" 25-34; Vieira and MacDonald, 203-221) stating that it is the most appropriate measure. However, some researchers through their studies showed that there 
is no substantial difference in using real or nominal exchange rate (Choudhry 51-71; McKenzie and Brooks 73-87)

Empirical literature proposes a number of methods to measure volatility. Agiomirgianakis et al. "Iceland" 25-34, "UK" 1-12, "Turkey" 700-725) and Chowdhury (700-706) have used standard deviation of the moving average of the logarithm of the real effective exchange rate to estimate exchange rate volatility (Agiomirgianakis et al. "Iceland" 25-34, "UK" 1-12, "Turkey" 700-725; Chowdhury 700-706). However, the main pit fall in this estimate is that it is unable to capture the impact of peak values of the exchange rate. Agiomirgianakis et al. and Peace et al. overcame this issue by using a separate variable to account for high and low peak values of the real effective exchange rate (Agiomirgianakis et al. "Iceland" 25-34, "UK" 1-12, “Turkey" 700-725; Peace et al. 48-55). Some measures, however, less frequently used in literature include the random walk model (Webber, 398-405), averages of absolute changes (Song and Witt, 2011), standard deviation of the exchange rate series and deviation from the trend (Ekanayake and Chatrna 51-67).

Choudhry points out that above mentioned volatility estimation methods disregard underlying stochastic process from which the exchange rates are created (51-71). Thus, many researchers (Al-Najjar 157-162; Bala and Asemota 89-116;Choudhry 51-71; Ekanayake and Chatrna 5167; Epaphra 121-143; Murari 22- 37; Pelinescu, 543 - 549; Pilbeam and Langeland, 127-142; Thorlie, et al., 1206-1214; Vieira and MacDonald, 203-221) have used conditional variance of the first difference of the $\log$ of the exchange rate as volatility where conditional variance is estimated by the Autoregressive Conditional Heteroskedasticity ( $\mathrm{ARCH}$ ) model introduced by Engleand its extension, Generalized Autoregressive Conditional Heteroskedasticity (GARCH) model which was developed to overcome the limitations of the ARCH by allowing longer memory and flexible lag structure, which was proposed independently by Bollerslev and Taylor to model volatility (Engle 987-1007; Bollerseley 307 327). These models account for dynamic conditional variance (Epaphra 121-143) as it allows conditional variance to change over time as a function of past errors as opposed to constant variance assumption in conventional time series models (Al-Najjar 155-162). In addition, these models have become popular among researchers as they enable them to measure the variance of a series at a specific point in time (Enders, Applied Econometric Time Series 2).

These models also have an ability to capture inherent characteristics of volatility clustering and leverage effects in financial time series like exchange rate series (Choudhry 51-71; Epaphra 121-143; Thorlie, et al., 1206-1214). Volatility clustering is basically accumulation or gathering of information (Engel and West, 2005). It is described as the tendency of high positive or negative changes in asset prices to be followed by relatively high changes whereas small changes of either sign are expected to be followed by relatively small changes (Brooks 527545). It means that the current level of volatility is positively correlated with the volatility observed in immediately preceding periods (Epaphra 121-143). 
Empirical literature frequently observes that the depreciation in the exchange rate is followed by higher volatility (Abdalla 216-229; Murari 22- 37; Syarifuddin, et al., 35 - 54; Epaphra 121 143) which is referred as the leverage effect. In other words, price movement is negatively correlated with the volatility (Campbell and Kyle 1-34; Murari 22- 37). Leverage effect implies that conditional variance of the exchange rate return series can respond asymmetrically to positive or negative values of the exchange rate return series. However, GARCH models assume symmetric responses to positive or negative shocks (Epaphra 121-143). Thus, to overcome this limitation many asymmetric GARCH models have been developed as extensions of the simple GARCH model (Bala and Asemota 89-116). Among these models, the "Exponential Generalized Autoregressive Conditional Heteroskedasticity" (EGARCH) model (Nelson 347-370) and "GJR-GARCH" (Glosten et al. 1779-1801) are more popular (qtd. in Pilbeam and Langeland 127-142). Both EGARCH and GJR-GARCH models can extract the leverage effect but GJR-GARCH does not estimate log returns. Therefore, nonnegative constraints should be imposed. These non-linear extensions of the GARCH model use non-normal distributions (Student-t, Generalized Error Distribution and Skewed Studentt) since GARCH models sometime fail to capture the property of fat-tail, excess skewness and kurtosis of financial data (Thorlie et al. 1206-1214; Lahmiri 387-395).

\subsection{Research relating to exchange rate volatility and tourism sector in Sri Lankan context}

Ekanayake and Chatrna conducted an empirical investigation on the effect of exchange rate volatility on Sri Lankan exports (51-67). In their study, they measured volatility in the real effective exchange rate using the conditional variance derived from the GARCH $(1,1)$ model. The study reveals that depending on the type of export goods, the impact of exchange rate volatility differs, and they were unable to observe a firm connection among exchange rate volatility and Sri Lankan exports. Jayasekara estimate exchange rate volatility by relative change in real exchange rate in his study that focused on finding the effect of exchange rate volatility on foreign direct investments (75-96). This research revealed that stability in exchange rate will attract foreign direct investment into Sri Lanka.

Konarasinghe forecasts tourist arrivals to Sri Lanka during the post-war period based on monthly tourist arrival data using the Holt's Winter's three parameter model (57-63). However, it is accurate only for short term forecasting, thus, suggesting that using decomposition models such as ARCH, GRACH would be better for long term forecasts. Welgamage developed an econometric model based on the Cobb-Douglas function in order to analyse the relationship between foreign exchange earnings, tourist spending, tourist prices, tourist flows and employment in the tourism sector (90-101). This study reveals that foreign exchange earnings are significantly influenced by these variables. Moreover, foreign exchange earnings had a significant positive relationship with tourist spending, tourist flows and employment in the tourism sector, while tourist prices indicated a negative impact. Fernando et al. identify a significant seasonality in tourist flows to Sri Lanka with a large variability in monthly tourist 
arrivals to Sri Lanka (575-586). They argue that war related incidents are negatively related to tourist flows where tourist arrivals were reduced by $5.2 \%$ in comparison to a period in which peace prevailed. Lelwala and Gunaratne modelled tourism demand for Sri Lanka from the United Kingdom (UK) and find that the income of UK is the most important demand determinant (50-59). Selvanathan) in his research on "the effect of war and other factors on Sri Lankan tourism" concludes that there is a positive impact on tourism from the government's free trade policy and a negative influence on the tourism sector from war related incidents (35-38).

\section{Methodology}

\subsection{Model specification}

The main objective of this research is to evaluate the effect of exchange rate volatility on tourist flows into Sri Lanka. Earlier research studies in this area have modified the export demand function of Glodstein and Khan by incorporating an estimate of exchange rate volatility and including dummy variables to account for seasonal effects and special events (qtd. in Agiomirgianakis et al. "Iceland" 25-34, "UK" 1-12, "Turkey" 700-725; Arize, et al. 10-17; Ekanayake and Chatrna 51-67; Mwangi, et al. 1-12; Onafowora and Owoye 1547-1556; Serenis and Tsounis, 71-107). Thus, based on the existing empirical literature, this present study developed a standard long run tourism demand function for Sri Lanka as specified in the equation 1 below.

$$
\begin{aligned}
\ln X_{t}=\beta_{0}+\beta_{1} \ln _{t}+\beta_{2} \ln R P_{t}+\beta_{3} \ln V_{t}+\beta_{4} M_{1 t}+\beta_{5} M_{2 t}+\beta_{6} M_{3 t}+\beta_{7} M_{4 t}+\beta_{8} M_{5 t} \\
+\beta_{9} M_{6 t}+\beta_{10} M_{7 t}+\beta_{11} M_{8 t}+\beta_{12} M_{9 t}+\beta_{13} M_{10 t}+\beta_{14} M_{11 t}+\beta_{15} P_{t} \\
+\varepsilon_{t}
\end{aligned}
$$

Where $t$ is the time dimension, $\ln$ indicates that the variables are converted to their natural logarithm values, $X_{t}$ is the number of tourist arrivals at time t (a proxy for tourist demand), $I_{t}$ is the income at tourist origin at time $t$ proxied by industrial production indices of origin countries, $R P_{t}$ is the relative price, which is proxied by a ratio of Consumer Price Index (CPI) between destination country and origin country adjusted to exchange rates and $V_{t}$ an estimate of exchange rate volatility at time t. A separate exchange rate variable is not included to the above tourist demand model because relative price is standardized using a bilateral exchange rate and therefore the inclusion of an additional exchange rate variable will result in problems of multicollinearity and model bias, as explained in Section 2.1.3 of the literature review. The Loglinear transformation is adopted to minimise heteroskedasticity and it is the most appropriate and frequently used functional form in previous studies. 
$M_{1 t}$ to $M_{11 t}$ are seasonal dummies to account for monthly seasonality, $P_{t}$ is a dummy variable to represent the end of civil war in Sri Lanka with a value of 1 representing the period after the end of civil war (sample period of 2009 June to 2016 October) and 0 to represent the period of civil war in the sample (1990 January to 2009 May) whereas $\varepsilon_{t}$ is the error term. The inclusion of the dummy variable $P_{t}$ is further confirmed by Figure 1 , where an exponential growth is witnessed after 2009 May.

\subsection{Data sources and variable definitions}

This research study employed secondary time series data with monthly frequency starting from January of 1990 to October 2016. Accordingly, this study covers a period of approximately 27 years with 322 monthly observations for each variable considered in this research.

Tourist arrivals are used as the proxy for tourism demand since it is the most frequently used proxy in the literature. Moreover, tourism expenditure, which is a better proxy as explained in Section 2.1.1 of the literature review is not available in monthly frequency with the country disaggregation. The analysis focus on tourist arrivals from seven major country origins; namely, United Kingdom, India, Germany France, Australia, Japan and Netherland. These were selected based on an annual average rank for the period under investigation. A rank was given for each country for each year based on the annual tourist arrivals to Sri Lanka from that particular country. Then an average annual rank was computed, which is the average of ranks for the 27 years from 1990 to 2016. Subsequently, the aforementioned top seven countries (namely United Kingdom, India, Germany, France, Australia, Japan and Netherland) were selected based on this average rank so that it covers more than $50 \%$ of the tourist arrivals to Sri Lanka during the investigation period. The trend in tourist arrivals from these selected countries is given in Figure 1, below. It clearly indicates that there is an exponential growth after 2009 May with the end of the civil war. This further validates the inclusion of a dummy variable to incorporate this structural break into the tourism demand model specified under Section 3.1, above.

Historical data on monthly tourist arrivals to Sri Lanka with country disaggregation were not freely available in electronic format. Thus, the data was officially requested from the Sri Lankan Tourism Development Authority (SLTDA) and extracted from various issues of SLTDA's Annual Statistical reports, which were available at their library. 
Figure 1: Tourist Arrivals to Sri Lanka from United Kingdom, India, Germany France, Australia, Japan and Netherland

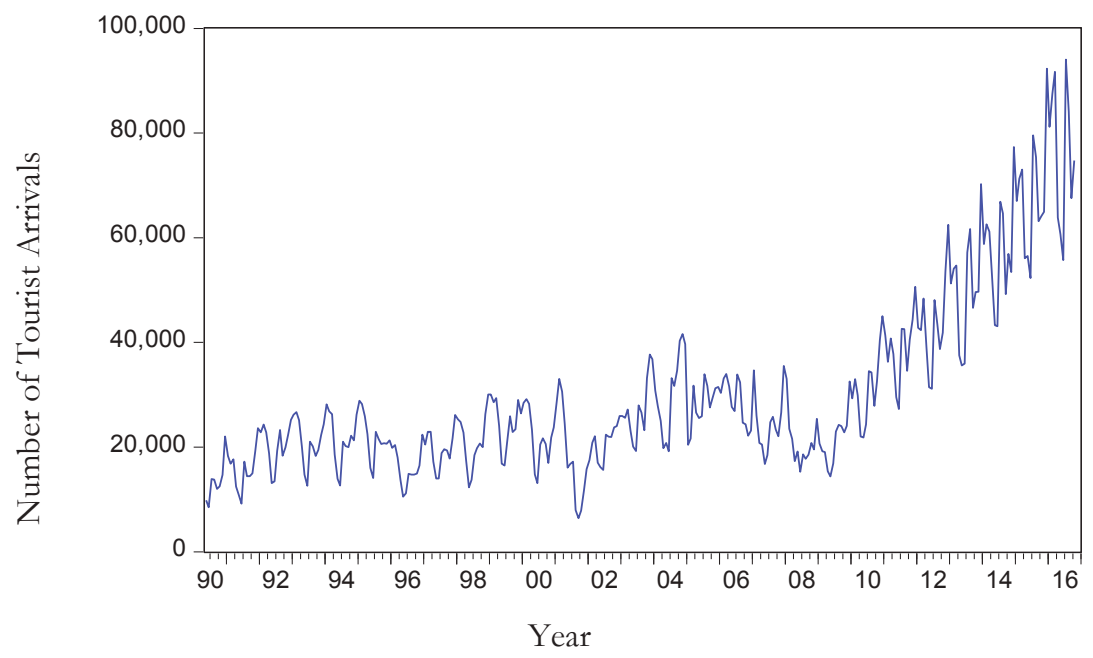

Source: Author's calculations based on data from IMF, IFS data base and SLTDA using Eviews® statistical software

In this study, the Industrial production Index (IPI) is used as the proxy for foreign income since personal disposal income or per capita GDP or GNI is not available with monthly frequency. As better explained in Section 2.1.1 of the literature review, IPI is advantageous in this scenario since it deals with monthly data. Thus, following Ekanayake and Chatrna, weighted average of IPIs of the selected seven major tourist origins were computed as follows,

$$
I_{t}=\sum_{j=1}^{7} W_{j t} I_{j t}
$$

Where $I_{t}$ is the real foreign income at time t, $W_{j t}$ is a weight representing the share of tourist arrivals from $j^{\text {th }}$ country to Sri Lanka at time $t$ from total tourist arrivals from the seven major tourist origin countries at time $t$, and $I_{j t}$ is the IPI of the $j^{\text {th }}$ country at time $t$ (Ekanayake and Chatrna 51-67). The seven major tourist origin countries are United Kingdom, India, Germany, France, Australia, Japan and Netherland. The respective IPI's (with the base year $2010=100$ ) of these selected countries were extracted from the International Monetary Fund (IMF)'s International Financial Statistics (IFS) database. However, in Australia, the IPI is calculated based on quarterly frequency, hence, the quadratic match average technique of low 
to high frequency conversion in Eviews ${ }^{\circledR}$ was used to convert these quarterly index values into monthly indices.

As explained in Section 2.1.2 of the literature review, the price factor includes two main components, namely cost of transport to and from destination and cost of living for tourist at destination. In this study only the cost of living component is taken into consideration due to the complexity in deriving a proxy for cost of transportation and lack of disaggregated data available to construct such estimates which is better explained in literature review. Literature reveals that the most appropriate proxy for tourist cost at destination is the tourism price index (Dwyer and Forsyth 751-777). A separate tourism price index is computed for Sri Lanka by the SLTDA, covering the tourist expenditure on accommodation, food and transport (Sri Lanka Tourism Development Authority). However, it is only computed on an annual basis with a considerable time lag. Further, this index was not available for some countries in the selected sample. In addition, since each national statistical institute use customised definitions it is practically difficult to arrive at an aggregate index. Thus, due to these practical issues and in order to maintain cross country homogeneity CPIs were used as the proxy to compute a measure for relative prices. Accordingly, this study also uses the most frequently used proxy for relative prices as better explained in Section 2.1.2 of the literature review. Following the concept of Gonzalez and Moral and Dogru et al. the relative price was computed as follows with a slight modification to include a weight to combine price relatives of the seven origin countries (Gonzalez and Moral 233-251; Dogru et al. 47-55):

$$
R P_{t}=\sum_{j=1}^{7} W_{j t} \frac{C P I_{S L, t}}{C P I_{j t} E R_{j t}}
$$

Where $P R_{t}$ is the relative price at time t, $W_{j t}$ is a weight representing the share of tourist arrivals from jth country to Sri Lanka at time $t$ from total tourist arrivals from the seven major tourist origin counties at time t, and monthly $C P I_{j t}$ is the monthly CPI of the jth country at time t, $C P I_{S L, t}$ is the monthly CPI of Sri Lanka at time t, and $E R_{j t}$ is the monthly average exchange rate, rupees per unit of currency in jth country at time t. The seven major tourist origin counties are United Kingdom, India, Germany, France, Australia, Japan and Netherland. The respective CPI's (with the base year 2010=100) of these selected countries were extracted from IMF's IFS database. However, in Australia, CPI is calculated based on quarterly frequency, hence, the quadratic match average technique of low to high frequency conversion in Eviews ${ }^{\circledR}$ was used to convert these quarterly values into monthly indices. The respective domestic currency exchange rate per USD of Sri Lanka and other countries considered in the sample were extracted from the IMF's IFS database and these were used to arrive at rupee rate per unit of currency in $j^{\text {th }}$ country since rupees per unit of currency in $j^{\text {th }}$ country was not available in the IMF statistics database. Germany, France and Netherland 
joined the European Union on 1st January 1999. Therefore, their domestic currency exchange rates were not available after this date. To overcome this issue from 1st January 1999, the Euro per USD exchange rate was considered and multiplied by respective irrevocable conversion rates for the euro, fixed by the Ministers of Finance of the countries making up the euro area, to create a measure for domestic currency exchange rate. The respective irrevocable conversion rates for Germany, France and Netherland were obtained through European commission's official website (European Commission). This conversion was necessary to maintain the consistency of the exchange rate series of these countries across the time period considered for this research.

Real effective Exchange rate (REER) was not available for Sri Lanka in the IMF, IFS database. The Central Bank of Sri Lanka (CBSL) published a REER (with latest base year=2010) with weights based on the proportion of bilateral trade to Sri Lanka's total foreign trade in 2010, which can be used as an indicator for the country's external competitiveness (CBSL Annual Report 2010 ). However, the figures are only available from 2003. Further, as stated by Dwyer and Forsyth this is not an accurate measure of competitiveness for the tourism industry because tourism trade patterns are different from the overall trade patterns (751-777). Thus, following Sekkat and Varoudakis, and Ekanayake and Chatrna, the tourism weighted real exchange rate, $R E R_{t}$, was constructed as,

$$
R E R_{t}=\sum_{j=1}^{7} W_{j t} \frac{E R_{j t} C P I_{j t}}{C P I_{S L, t}}
$$

Where $R E R_{t}$ is the real effective exchange rate at time t, $W_{j t}, E R_{j t}, C P I_{j t}$, and $C P I_{S L, t}$ are the same as defined above. A decrease in $R E R_{t}$ indicates an appreciation in exchange rate while an increase indicates a depreciation (Sekkat and Varoudakis 237-253; Ekanayake and Chatrna 51-67).

\subsection{Measuring exchange rate volatility}

As explained in detail in Section 2.3 of the literature review, this research uses conditional variance of the first difference of the log of the real effective exchange rate $\left(R_{t}\right)$ as volatility. First difference of the log of the real effective exchange rate $\left(R_{t}\right)$ is also termed as the exchange rate return series and is computed as;

$$
R_{t}=\ln \left(R E R_{t}\right)-\ln \left(R E R_{t-1}\right)
$$

Where $R E R_{t}$ is the real effective exchange rate at time t. The conditional variance of $R_{t}$ is estimated through an ARCH-type model. This method was selected due to its ability to capture inherent features such as volatility clustering, leverage effect, excess kurtosis, skewness and fat 
tail properties observed in financial series as better explained in Section 2.3 of the literature review.

Among the ARCH type models presented in the literature, the EGARCH (Nelson 347-370) model is selected to derive the required conditional variance in this research, since conditional variance will be positive even if the parameters are negative, as it measures log returns. Thus, non-negative constraints need not be imposed artificially (Brooks 527-545) and it has an ability to capture the asymmetry in volatility clusters, which is the leverage effect (Pelinescu 543 549). The EGARCH $(1,1)$ model of Nelson which is estimated in this research based on AR (3) model for mean equation is defined as follows (qtd. in Brooks 527-545),

$$
\begin{gathered}
\ln \left(\sigma^{2}{ }_{t}\right)=\omega+\lambda \ln \left(\sigma^{2}{ }_{t-1}\right)+\theta \frac{u_{t-1}}{\sqrt{\sigma^{2}{ }_{t-1}}}+\gamma\left[\frac{\left|u_{t-1}\right|}{\sqrt{\sigma^{2}{ }_{t-1}}}-\sqrt{\frac{2}{\pi}}\right] \\
R_{t}=c+\alpha_{1} R_{t-1}+\alpha_{2} R_{t-2}+\alpha_{3} R_{t-3}+u_{t-1}
\end{gathered}
$$

Where 6 is the conditional variance equation and 7 is the mean equation, $\sigma^{2}{ }_{t}$ is the one period ahead conditional variance, which is estimated from past information. This estimated conditional volatility is used as the measure of volatility in this research. $\omega, \lambda, \theta$ and $\gamma$ are parameters to be estimated. There are no restrictions for $\omega, \theta$ and $\gamma$ but $\lambda$ must be positive and less than one to maintain stationarity. $\theta$ measures the leverage effect or asymmetry in volatility clusters. If $\theta$ is negative and significant then it implies that the leverage effect is present ( Epaphra 121-143). It implies that positive shocks create less volatility than negative shocks of the same magnitude (Brooks 527-545; Ali 57-73). $\lambda$ measures the persistence of conditional volatility, where large and significant estimate for the parameter implies that volatility takes a long time to reduce after a shock in the system (Alexander). $\gamma$ represents the GARCH effect or the symmetric effect (Epaphra 121-143).

As better explained by Lahmiri the choice of distribution assumption also impacts the performance of the EGARCH model (387-395). Thus, the Generalized Error Distribution is selected because of its capability in capturing excess kurtosis in time series (Nelson, 347-370; Lopez 87-109; Marcucci 1-55; Lahmiri, 387-395).

\subsection{Estimation method}

Stationarity of the variables was assessed using both the Phillips-Perron (PP) test (Phillips and Perron 335-346) and Augmented Dickey-Fuller (ADF) test (Dickey and Fuller 427-431) to corroborate the robustness of the tests and to ensure the inference on stationarity does not 
depend on the selection of the test. Engle and Granger and Johansen and Juselius have proposed methods for assessing the existence of cointegration or long run equilibrium relationship among the variables (Engle and Granger 251-276; Johansen and Juselius 169-210). However, Engle and Granger's method has a limitation since it only assumes the existence of one cointegrated relationship (251-276). Therefore, the method proposed by Johansen and Juselius is used to evaluate the existence of cointegration and the number of cointegrated equations (169-210).

If the variables are non-stationary, the common remedy is to make them stationary by using the first difference of the variables. However, when the association among variables are vital, such a method is not suitable as pure first differenced models have no long run solution. This problem could be rectified by using an error correction or equilibrium correction model, which uses a combination of first differenced and lagged levels of cointegrated variables (Brooks 527545).

The Engle- Granger representation theorem states that if the cointegrated relationship exists among a set of variables that are not stationary at level then it infers that a short run error correction relationship exists among them (251-276). Enders states that if long run elasticities exist, then it is rational to evaluate how short run behavior will respond to long run elasticities (Applied Econometric Time Series 3).

According to Engle and Granger deviated actual tourist arrivals are expected to return to its long run equilibrium (251-276). The short run relationship of this research can be denoted through an error correction model, as follows;

$$
\begin{gathered}
\Delta \ln X_{t}=\alpha_{0}+\alpha_{1} E C_{t-1}+\sum_{l=1}^{m} \beta_{i} \Delta \ln X_{t-i}+\sum_{l=0}^{m} \eta_{l} \Delta \ln I_{t-1}+\sum_{l=0}^{m} \delta_{l} \Delta \ln R P_{t-1} \\
+\sum_{l=0}^{m} \varphi_{l} \Delta \ln V_{t-1}+\omega_{t}
\end{gathered}
$$

The first difference of tourist arrivals is a function of lagged tourist arrivals, current and lagged values of the independent variable and the lagged value of long run disturbance term $\left(E C_{t-1}\right)$ (i.e., the residuals generated from the long run model given by the equation 1 ). According to Engle and Granger coefficient of the long run disturbance term reflects the short run adjustment and indicates the speed of adjustment towards long run equilibrium state where a high coefficient implies a rapid adjustment (251-276). Moreover, it measures the proportion of the previous period's equilibrium error that is corrected for. Whereas $\beta_{i}$ 's denotes the short run relationship between changes in independent and dependent variables. 


\subsection{Model Validity}

Model diagnostic was performed in order to evaluate the adequacy of the fitted models. Goodness of the fit of the model is assessed based on residuals (Epaphra 121-143). The residuals are assumed to be independently and identically distributed following a normal distribution (Gourieroux and Jasiak).

\section{Analysis and discussion of the findings}

\subsection{Measuring volatility in the real effective exchange rate}

As explained in detail in the Section 3.3 of the Methodology, this research uses conditional variance of the first difference (or change) of the log of the real effective exchange rate $\left(R_{t}\right)$ as volatility. The first difference (or change) of the log of the real effective exchange rate $\left(R_{t}\right)$ is hereafter referred to as exchange rate return series.

Figure 2: Exchange rate return $\operatorname{series}\left(\boldsymbol{R}_{t}\right)$

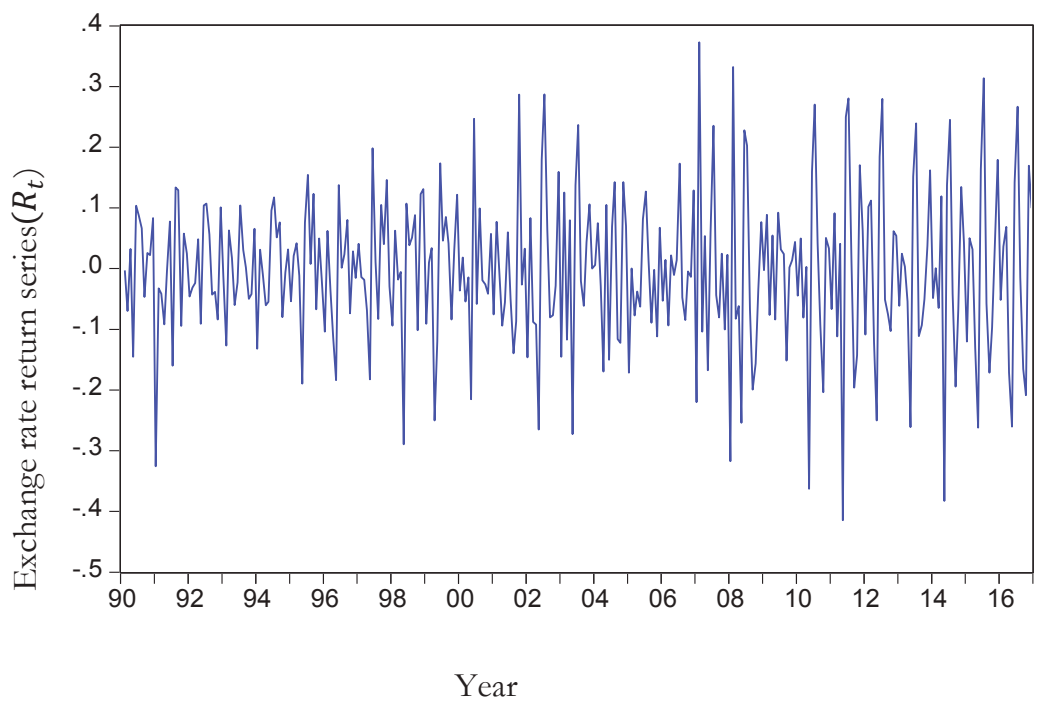

Source: Author's calculations based on data from IMF, IFS data base and SLTDA using Eviews ${ }^{\circledR}$ statistical software

Figure 2 illustrates that volatility occurs in clusters and hence provides evidence of timevarying volatility in exchange rate return series. This is referred to as the presence of the $\mathrm{ARCH} / \mathrm{GARCH}$ effect and further validates the use of an ARCH type model. The ADF test was performed to identify unit roots in return series. The results of the test are presented in Table 1. The test rejects the null hypothesis of unit roots in the series and confirms that the exchange rate return series is stationary. Since the series is stationary the best fitting mean equation is identified through applying Autoregressive Moving Average (ARMA) to select the best process to model the conditional mean, which was identified as AR (3) process. 


\section{Table 1: Augmented Dickey Fuller test}

H0: There exists a Unit Root (i.e. the process is not stationary) H1: No Unit Root exists (i.e. the process is stationary)

t-Statistic

$-6.156122$
Prob.*

0.0000

Augmented Dickey-Fuller test statistic $\quad-6.156122 \quad 0.0000$

*MacKinnon (601-618) one-sided p-values.

Source: Author's calculations based on data from IMF, IFS data base and SLTDA using Eviews@ statistical software.

In order to obtain the conditional variance of the exchange rate return series $\left(R_{t}\right)$, as clearly explained in Section 3.3 of the Methodology, the EGARCH $(1,1)$ model is fitted based on $\operatorname{AR}(3)$ mean equation and equations 6 and 7 are estimated for the period from February 1990 to December 2016, with Generalized error distribution assumption using Eviews ${ }^{\circledR}$ statistical software. Table 2 below shows the results of the estimated equations. 
Table 2: Estimation of conditional variance of the exchange rate return $\operatorname{series}\left(\boldsymbol{R}_{t}\right)$ as a EGARCH $(1,1)$ process

$$
\begin{gathered}
R_{t}=0.001898-0.340690 R_{t-1}-0.315027 R_{t-2}-0.331853 R_{t-3}+u_{t-1} \\
\begin{array}{ccc}
0.7418) & (0.0000)^{* * *} \quad(0.0000)^{* * *} \quad(0.0000)^{*}
\end{array} \\
\ln \left(\sigma_{t}^{2}\right)=-2.218891+0.458877 \ln \left(\sigma^{2}{ }_{t-1}\right)-0.369409 \frac{u_{t-1}}{\sqrt{\sigma^{2}{ }_{t-1}}}-0.272486\left[\frac{\left|u_{t-1}\right|}{\sqrt{\sigma^{2} t-1}}-\sqrt{\frac{2}{\pi}}\right] \\
(0.0078)^{* * *} \quad(0.0164)^{* *} \quad(0.0004)^{* * *} \quad(0.0650)^{*}
\end{gathered}
$$

$\mathrm{R}^{2}=0.21 \quad$ Durbin Watson $=1.91 \quad$ F-Statistic $=10.06(0.0000)^{* *}$

Note: The figures in parentheses are p-values; ***, ** and * indicate the statistical significance at the $1 \%, 5 \%$ and $10 \%$ level, respectively.

Source: Author's calculations based on data from IMF,IFS data base and SLTDA using Eviews® statistical software.

As explained clearly in Section 3.3 of the Methodology, $\lambda$ should be positive and less than one to maintain stationarity. Accordingly, it can be observed from Table 4.1 that $\lambda(=0.458877)$ is positive, significant at $5 \%$ and less than one, indicating that the estimated EGARCH model is stationary. In addition, the value is not large and it is significant, which means that the persistence of conditional volatility is moderate. In other words, volatility takes only an average time to reduce after a crisis in the market.

$\theta(=-0.369409)$ is negative and significant even at $1 \%$, implying that the leverage effect is present. This reveals that negative shocks imply a higher next period volatility than positive shocks of the same sign. This is in line with the results of previous studies (Abdalla 216-229; Murari 22- 37; Syarifuddin, et al., 35 - 54; Epaphra 121-143), which revealed that the depreciation in the exchange rate is followed by higher volatility. $\gamma(=0.0650)$ which represents the GARCH effect or the symmetric effect is significant only at $10 \%$.

The goodness of the fit of the model is assessed through residual diagnostic tests, as explained in Section 3.5 of the Methodology. Durbin Watson statistic (=1.91) is close to 2, indicating no serial correlation among residuals. Serial correlation in residuals are further tested using autocorrelation (ACF) and partial autocorrelation (PACF) functions of the residuals, together with the Ljung-Box Q-statistics (Q-Stat) for higher order serial correlation. The results of these tests are given in Table 3. 
Table 3: Serial Correlation Test

\begin{tabular}{lllll}
\hline \hline Lag & ACF & PACF & Q-Stat & P-value \\
\hline 1 & 0.057 & 0.057 & 1.0668 & 0.302 \\
2 & -0.102 & -0.105 & 4.4106 & 0.110 \\
3 & -0.076 & -0.064 & 6.2662 & 0.099 \\
4 & -0.079 & -0.083 & 8.3014 & 0.081 \\
5 & -0.060 & -0.068 & 9.4932 & 0.091 \\
6 & -0.081 & -0.100 & 11.662 & 0.070 \\
7 & -0.014 & -0.032 & 11.723 & 0.110 \\
8 & -0.068 & -0.107 & 13.267 & 0.103 \\
\hline
\end{tabular}

Source: Author's calculations based on data from IMF, IFS data base and SLTDA using Eviews® statistical software.

It is evident from Table 3 that there is no serial correlation in the model since none of the lags are found to be significant at a $5 \%$ level to reject the null hypothesis of no serial correlation in residuals, confirming the adequacy of the fitted model. Further, Table 4 reveals that the ARCH-LM test doesn't reject the null hypothesis of no ARCH effects in the residuals, thus confirming that the conditional heteroskedasticity existed in the exchange rate return series is successfully modelled and no ARCH effect is left in the residual. This further confirms the adequacy of the fitted model. Therefore, predicted values of the conditional variance from the fitted EGARCH $(1,1)$ model were taken as the estimate of volatility of the real effective exchange rate, which is used in the tourism demand model of this research.

Table 4: Heteroskedasticity Test: ARCH-LM Test

\begin{tabular}{ll}
\hline \hline F-Statistic & Prob. F $(1,317)$ \\
\hline 0.473020 & 0.4921
\end{tabular}

Source: Author's calculations based on data from IMF, IFS data base and SLTDA using Eviews ${ }^{\circledR}$ statistical software.

\subsection{Stationarity of the variables}

To check for stationarity, the Augmented Dickey-Fuller (ADF) test (Dickey and Fuller 427431) and Phillips-Perron (PP) test (Phillips and Perron, 335-346) were applied to each variable at the level and the first difference. The null hypothesis of these unit root tests is that the series has a unit root or in other words the series under consideration is non-stationary, while the alternative hypothesis is that the time series considered is stationary. The results of these Unit root tests are given in Table 5. 
Table 5: Unit Root (ADF and PP) Tests Results

H0: There exists a Unit Root (i.e. the process is not stationary) H1: No Unit Root exists (i.e. the process is stationary)

\begin{tabular}{|c|c|c|c|c|c|}
\hline \multirow{2}{*}{ Variable } & \multicolumn{2}{|c|}{ P-Value at Level } & \multicolumn{2}{|c|}{ P-Value First Difference } & \multirow{2}{*}{$\begin{array}{l}\text { Order of } \\
\text { Integration } \mathrm{I}(\mathrm{d})\end{array}$} \\
\hline & $\mathrm{ADF}$ & PP & $\mathrm{ADF}$ & PP & \\
\hline $\ln X$ & 0.9584 & 0.9218 & $0.0000^{*}$ & $0.0000^{*}$ & $\mathrm{I}(1)$ \\
\hline $\ln I$ & 0.9246 & 0.9693 & $0.0001^{*}$ & $0.0001 *$ & $\mathrm{I}(1)$ \\
\hline $\ln R P$ & 0.2507 & 0.4073 & $0.0000^{*}$ & $0.0000^{*}$ & $\mathrm{I}(1)$ \\
\hline $\ln \mathrm{V}$ & 0.6713 & 0.5467 & $0.0000^{*}$ & $0.0001 *$ & $\mathrm{I}(1)$ \\
\hline
\end{tabular}

*The null hypothesis is rejected since the P-value is less than $5 \%$ significant level

Source: Author's calculations based on data from IMF, IFS data base and SLTDA using Eviews ${ }^{\circledR}$ statistical software It is evident from Table 5 that all the variables $\ln \mathrm{X}, \ln \mathrm{I}, \ln \mathrm{R}$ and $\ln \mathrm{V}$ have unit roots in the level (i.e., Not stationary) under a 5\% significant level. However, when unit root tests are performed on the first differences of these variables, the tests reveal that first differenced series are stationary. Hence, it can be concluded that all the variables are integrated of order one.

\subsection{Cointegration analysis}

Section 4.2 reveals that all the variables are integrated of order one. Therefore, the method proposed by Johansen and Juselius is used to evaluate the existence of cointegration and the number of cointegrated equations (169-210).

The result of the Johansen and Juselius cointegration test is given in Table 6 and it reveals that the null hypothesis of no cointegation is rejected at $5 \%$ level of significance. Both Trace and Maximum Eigen value cointegration tests denote that there exists one significant cointegrating vector in the system. Moreover, this suggests that there is a unique long run equilibrium relationship among the variables. Therefore, Engle and Granger's two step method is used to estimate the error correction model since there is only one cointegated equation. 
Table 6: Johansen's Test for Cointegration

\begin{tabular}{lcccc}
\hline \hline & \multicolumn{2}{c}{ Trace } & \multicolumn{2}{c}{ Maximum Eigen Value } \\
\cline { 2 - 5 } Ho $_{0}$ No. of Cointegration equations & Test Statistic & p-value*** & Test Statistic & p-value*** \\
\hline None* & 68.74480 & 0.0002 & 41.37394 & 0.0005 \\
At most 1** & 27.37087 & 0.0929 & 20.32274 & 0.0646 \\
At most 2 & 7.048129 & 0.5720 & 6.706073 & 0.5245 \\
At most 3 & 0.342056 & 0.5586 & 0.342056 & 0.5586 \\
\hline
\end{tabular}

* Existence of at least one cointegrating vector (i.e. reject the null hypothesis at 5\% significance)

** Existence of maximum of one cointegrating vector (i.e. do not reject of null hypothesis at $5 \%$ significance)

***MacKinnon-Haug-Michelis (1999) p-values

Source: Author's calculations based on data from IMF,IFS data base and SLTDA using Eviews ${ }^{\circledR}$ statistical software

\subsection{Estimating long run Tourism Demand Model}

The first step in the Engle and Granger method is the estimation of the long run relationship. The long run tourism demand model which is developed following empirical literature is specified in equation 1 in the Section 3.1 of the Methodology.

Therefore, as the first step, this model is estimated, and the residuals of this model are constructed, and it was tested for stationarity using Phillips-Perron (PP) unit root test (Brooks). The estimation of the tourism demand model yielded the following cointegrated equation.

$$
\begin{aligned}
\ln X_{t}=3.969841 & +1.369242 \ln _{t}+0.155351 \ln R P_{t}-0.091340 \ln V_{t}-0.052469 M_{1 t} \\
& -0.038151 M_{2 t}-0.187027 M_{3 t}-0.276691 M_{4 t}-0.444709 M_{5 t} \\
& -0.513591 M_{6 t}-0.118102 M_{7 t}-0.132471 M_{8 t}-0.372547 M_{9 t} \\
& -0.332925 M_{10 t}-0.217922 M_{11 t}+0.505152 P_{t}
\end{aligned}
$$

Where, $\ln$ represents natural logarithm, $X_{t}$ is the number of tourist arrivals at time $t$ (a proxy for tourist demand), $I_{t}$ is the income at tourist origin at time t proxied by weighted industrial production indices of origin countries, $R P_{t}$ is the relative price, which is proxied by weighted ratio of Consumer Price Index (CPI) between destination country and origin country adjusted to exchange rates and $V_{t}$ an estimate of exchange rate volatility at time $t$ given by EGARCH(1,1) process. $M_{1 t}$ to $M_{11 t}$ are seasonal dummies to account for monthly seasonality, $P_{t}$ is a dummy variable to represent the end of civil war in Sri Lanka, with a value 
of 1 representing the period after the end of civil war (sample period of 2009 June to 2016 October, i.e., the period where peace prevailed) and 0 to represent the period of civil war in the sample (1990 January to 2009 May).

As revealed by the coefficient of the exchange rate volatility variable $\left(V_{t}\right)$ in equation 9 , it has a negative long run effect on tourist arrivals with an elasticity of 0.091340 .This implies that exchange rate volatility tends to deter tourism demand in the long run since high volatility affects the choice of destination of risk averse tourist as well as tour operators. This negative relationship is in line with the findings of empirical literature (Peace et al. 48-55; Agiomirgianakisa et al. "Iceland" 25-34, "UK" 1-12, "Turkey" 700-725; Saayman and Saayman, 104-121). Moreover, it is expected that the number of risk averse tourists are significantly larger than risk lovers (Webber 398-405) and tour operators may shift locations to avoid exchange rate volatility, since the industry is dominated by package tourists (Agiomirgianakisa et al. "Iceland" 25-34).

Income at tourist origin $\left(I_{t}\right)$ has a positive long run effect on tourist arrivals with an elasticity of 1.369242. This indicates that as income increases, tourists spend an increasing share of their income on foreign tours. This direction is in line with economic theory as well as empirical literature (Cheng167-181; Peng, et al., 611-633). Moreover, as income elasticity is greater than one, the tourism product of Sri Lanka can be considered as a luxury good.

The relative price $R P_{t}$ variable is positive with an elasticity of 0.155351 . This finding is in line with Agiomirgianakis et al. study (Agiomirgianakis et al. "UK" 1-12) but against standard economic theory that emphasises that rise in price level results in reduced demand for most of the goods and services. This does not mean that Sri Lankan Tourism is a Giffen good, but tourist visit Sri Lanka for the unique tourism product it offers. As highlighted by Crouch this may also be due to a strong income effect that outweighs the substitution effect ("Demand Elasticities" 117-136). Further, the proxy used for the relative price variable, which is the weighted ratio of CPIs between destination country and origin country adjusted to exchange assumes that domestic tourism at the origin country is a substitute for foreign travel to the destination country. This assumption may not be true for the seven origin countries considered in this research.

The peace dummy $\left(P_{t}\right)$ that is incorporated in the tourism demand model to distinguish the period where peace prevailed has a positive long run effect on tourist arrivals. This emphasises that political stability is a necessity in order to boost tourism demand, which is reflected by the fact that the period where peace prevailed in Sri Lanka has a positive influence on the quantity of tourist flows to the country.

However, it should be noted at this stage that it is not possible to test the hypothesis regarding the cointegated relationship (Brooks). 
The result of the Phillips-Perron (PP) unit root test on the residuals of the long run tourism demand model is given in Table 7 and it reveals that the residuals are stationary, confirming the existence of a cointegration among these variables. These residuals form the Error Correction term (EC) of the short run model.

Table 7: Unit Root test on the residuals

\begin{tabular}{lll}
\hline \hline & Adj. t-Statistic & Prob.* $^{*}$ \\
\hline Phillips-Perron test statistic & -4.599101 & 0.0000 \\
\end{tabular}

*MacKinnon (601-618) one-sided p-values.

Source: Author's calculations based on data from IMF, IFS data base and SLTDA using Eviews ${ }^{\circledR}$ statistical software

\subsection{Error Correction Model}

The short run dynamics of the tourism demand function is evaluated through estimating an error correction model, as suggested by Engle and Granger and applied frequently in empirical literature (Choudhry 51-71; Mwangi, et al. 1-12; Ekanayake and Chatrna 51-67). The error correction model for this research as specified in equation 8 following Henry's (qtd. in Ekanayake and Chatrna 51-67 and Choudhry 51-71) general to specific modelling strategy. Initially, it involves regressing the first difference of tourist arrivals on a constant term, one lag error correction term $\left(E C_{t-1}\right)$ and zero to eight lags of first difference of each variable in equation 1 . Then as stated by the general to specific method, final parsimonious specification was achieved by reducing the dimensions by eliminating insignificant coefficients. In this general to specific approach, statistical adequacy of the model and diagnostics tests are given priority with an examination of inference drawn from theory hold until a statistical adequate model is found (Brooks).

The results of the estimated error correction model are given in Table 8. Where ln represents natural logarithm, the symbol $\Delta$ is the first difference operator, $X_{t}$ is the number of tourist arrivals, $I_{t}$ is the income at tourist origin, $R P_{t}$ is the relative price, $V_{t}$ an estimate of exchange rate volatility and $E C_{t-1}$ is the error correction term. 
Table 8: Results of the error correction model

\begin{tabular}{cccc}
\hline \hline Variable & Coefficient & Standard error & P value \\
\hline Constant & 0.007313 & 0.008531 & 0.3920 \\
$E C_{t-1}$ & $-0.124359^{* *}$ & 0.031958 & 0.0001 \\
$\Delta \ln X_{t-5}$ & $0.149074^{* *}$ & 0.043622 & 0.0007 \\
$\Delta \ln I_{t-5}$ & $0.288492^{* *}$ & 0.133678 & 0.0317 \\
$\Delta \ln R P_{t}$ & $-0.735113^{* *}$ & 0.051030 & 0.0000 \\
$\Delta \ln V_{t}$ & $-0.069405^{* *}$ & 0.019901 & 0.0006
\end{tabular}

R2=0.45; F-statistic $=49.4\left(0.00^{* *}\right) ;$ Durbin-Watson stat $=2.12$

** denotes significance at $5 \%$ level

Source: Author's calculations based on data from IMF, IFS data base and SLTDA using Eviews® statistical software

The Table 8 indicates that, as theoretically predicted, the error correction term has the appropriate negative sign and it is statistically significant at a $5 \%$ level. Since the error correction term is significant it is implied that the Sri Lanka's tourism demand model adjusts to changes in the independent variables. This reconfirms the presence of a steady long run equilibrium relationship between the variables in the cointegrating equation. Further, this validates the use of the error correction mode and reconfirms that the variables are cointegrated. As revealed by the coefficient of the error correction term, only 12.44 per cent of the disequilibrium is eliminated in one month. These estimates of error correction model suggest that if there are no further shocks, the gap to revert back to equilibrium would be closed within approximately eight months. Thus, it reveals that adjustment takes a relatively long time. Moreover, adjustment of tourist arrivals to any change in the independent variables of the tourist demand model takes a long time to return to the equilibrium.

The coefficients of the lagged values of $\Delta \ln I_{t}, \Delta \ln R P_{t}$ and $\Delta \ln V_{t}$ are short run parameters, measuring the short run immediate impact of independent variables on the dependent variable $\Delta \ln X_{t}$.

The estimated coefficient of the first difference of exchange rate volatility $\left(\Delta \ln V_{t}\right)$ which is the growth of volatility is significant and has the expected negative sign similar to the relationship observed in the long run model. This means that a unit change in the exchange rate volatility will impact the Sri Lankan tourism demand negatively. Further, the coefficient of the short run model is smaller than the coefficient of the long run model indicating that the 
exchange rate volatility has a smaller effect on tourism demand in the short run when compared to the long run.

The estimated short run coefficient of the first difference of income at tourist origin $\left(\Delta \ln I_{t-5}\right)$, which is the approximate growth of income, is significant and positive as in the long run but smaller in magnitude. This implies that Unit change in income at the tourist origin has a positive impact on Sri Lankan tourism demand, hence tourism is considered as a luxury good in the short run as well. However, the impact will come with a lag of five months.

It is interesting to note that the first difference of the price relative $\left(\Delta \ln R P_{t}\right)$ variable, which is the approximate rate of inflation, has a significant negative impact on the growth in tourist arrivals in the short run. This implies that tourists are price sensitive in the short run where a unit change in price will have negative impact on tourist arrivals to Sri Lanka. However, it is evident in the long run that the sensitivity had reduced partly due to higher income effects than the substitute effect or due to the fact that tourists consider the unique tourism product Sri Lanka offers rather than the associated price.

The coefficient of the lagged first difference of tourist arrivals $\left(\Delta \ln X_{t-5}\right)$, which is the growth rate of tourist arrivals before five months has a significant positive impact on the current growth of the tourist arrivals. This can be interpreted as the impact of word of mouth recommendation or habit persistence (Witt and Witt 447-475). Habit persistence means once people have visited a specific country and if they like it they will tend to return since they know it's less risky than vising an unknown destination.

\subsection{Model Validity}

The coefficient of multiple determination (R2) of the fitted error correction model is 0.45 (Refer Table 8 ). It denotes that $45 \%$ of the variance in the volume of tourist arrivals are predicted by the independent variables. This indicates that the explanatory power of the independent variables is moderate. F statistics is also significant even at a $1 \%$ level, indicating that the variation in the long run tourist arrivals can be attributable to changes in the independent variables. In addition, as explained in detail under Section 3.5, the model diagnostic based on residuals need to be carried out to evaluate the adequacy of the fitted error correction model.

The Durbin-Watson (DW) is 2.12 (Refer Table 8), inferring no serial correlation among residuals. In addition, correlograms and Q- statistics were also computed to assess the serial correlation and the results are presented in Table 9. It is evident from Table 9 that ACF and PACF values are closer to zero and Ljung-Box Q-statistics are insignificant at a 5\% level, which indicates that the null hypothesis of no serial correlation among residuals is not rejected, which further confirms the results of the DW test. 
Table 9: Serial Correlation Test for the residuals from the Error Correction model

\begin{tabular}{ccccc}
\hline \hline Lag & ACF & PACF & Q-Stat & P-value \\
\hline 1 & -0.065 & -0.065 & 1.3274 & 0.249 \\
2 & 0.019 & 0.015 & 1.4466 & 0.485 \\
3 & -0.097 & -0.096 & 4.4539 & 0.216 \\
4 & -0.028 & -0.041 & 4.7003 & 0.319 \\
5 & -0.033 & -0.035 & 5.0413 & 0.411 \\
\hline
\end{tabular}

Source: Author's calculations based on data from IMF, IFS data base and SLTDA using Eviews® statistical software

The Breusch-Pagan-Godfrey (BPG) Heteroskedasticity Test was performed to identify Heteroskedasticity in residuals. The test results are presented in Table 10 and results indicate that the null hypothesis of no Heteroskedasticity in residuals is not rejected at a $5 \%$ significance level. This implies that the residuals series of the fitted error correction model is homoscedastic. Thus, the fitted model fulfilled all diagnostic tests. Therefore, it can be concluded that the model is adequate to capture the variations of the considered variables. In other words, Sri Lanka's tourism demand can effectively be explained using the specified independent variables.

Table 10: Heteroskedasticity Tests: Breusch-Pagan-Godfrey (BPG)

\begin{tabular}{ll}
\hline \hline F-Statistic & Prob. F(1,317) \\
\hline 0.863053 & 0.5062
\end{tabular}

Source: Author's calculations based on data from IMF, IFS data base and SLTDA using Eviews ${ }^{\circledR}$ statistical software

\section{Concluding remarks and policy implications}

The main objective of this study is to ascertain the effect of exchange rate volatility on tourist flows into Sri Lanka and its implications on tourism policy, with the secondary objectives of identifying the effect of income at origin (i.e. income elasticity) and effect of relative prices between destination and origin (i.e. Price elasticity) on tourism demand, which is measured 
through tourist arrivals to Sri Lanka. The empirical research provides ambiguous conclusions regarding these relationships depending on the different country combinations. Thus, identifying the impact of these tourism demand determinants in the Sri Lankan context provides a foundation for destination development planning as well as to the development of customised marketing strategies.

The dynamic relationship between tourist arrivals, exchange rate volatility, income at origin and relative prices were assessed using the theory of cointegration and error correction representation, using monthly data from 1990 to 2016.

In this context, the real effective exchange rate volatility was measured by conditional variance of the estimated Exponential Generalized Autoregressive Conditional Hetroscedasticity (EGARCH $(1,1))$ model given by equations 6 and 7 since the ARCH effect existed in the data. Results reveal that in the Sri Lankan context volatility takes a moderate time to reduce after a crisis in the market. Further, as revealed by the significant and negative leverage effects the depreciation in exchange rate is followed by higher volatility in Sri Lankan context which is in line with the findings of empirical literature (Brooks 527-545; Ali 57-73). Then the study used the Augmented Dickey-Fuller (ADF) test (Dickey and Fuller 427-431) and Phillips-Perron (PP) test (Phillips and Perron, 335-346) to each variable used in this study to test their long run stability or stationarity. The results revealed that all the variables have unit roots, thus, it is concluded that they are not stationary. The method introduced by Johansen and Juselius was used to identify whether these non-stationary variables are cointegrated which revealed that these are cointegrated with the unique long run equilibrium relationship of tourism demand model, as given in equation 1(Johansen and Juselius 169-210).

Finally, the error correction model given by equation 8 is estimated to detect the speed of adjustment to the long run equilibrium path with sudden shocks in the short run. The coefficient of the error correction term is negative and statistically significant with a value of 0.1244. This reconfirms the presence of a steady equilibrium long run association among the variables and the negative sign of the coefficient indicates that the correction or the rectification is towards the long run equilibrium. The adjustment of tourist arrivals to any variation in the independent variables of the tourist demand model takes a long time to return to equilibrium since based on the magnitude of the coefficient of the error correction term only 12.44 per cent of the disequilibrium is eliminated in one month and total adjustment will take approximately eight months. This implies that the market forces in tourism market do not restore equilibrium quickly.

The study concludes that the exchange rate volatility has a significant negative impact on tourist flows into Sri Lanka both in the short run as well as in the long run. A volatile exchange rate increases uncertainty and transaction costs. Moreover, economic, political and social instability is often reflected by a volatile exchange rate. Thus, this adversely impact the choice of destination of risk averse tourists as well as tour operators. Majority of the previous research 
(Peace, et al. 48-55; Agiomirgianakisa, et al. "Iceland" 25-34, "UK” 1-12, “Turkey" 700-725; Aktaş and Özkan 493-499; Saayman and Saayman, 104-121; Webber, 398-405) have also identified this negative relationship, thus findings of this research are encouraging. Therefore, the findings suggests that policy makers should take necessary actions to maintain the stability and the competitiveness of the exchange rate. Thus, when designing trade policies due consideration should be given to the impact of these policies on exchange rate volatility as well as its competitiveness. However, this stabilization should not be achieved through high inflation (Goldfajn and Gupta 90-114). In addition, tourism policy makers should limit targeting tourist markets that are prone to economic, social and political instability that could result in volatile exchange rates, since it will impact tourist flows from those countries negatively. Hence, it will eventually increase uncertainty on the return on investment in marketing.

In line with economic theory as well as empirical literature, it was found that the Sri Lankan tourism product is a luxury good, thus having a high-income elasticity, which is related to an increase in purchasing power with increasing real income. This suggests that tourism policy makers should target countries with stable economic growth and high per capita income when designing promotional campaigns, which will ensure a stable tourism demand in the long run. Moreover, Peng et al. (611-633) through their research concluded that tourists who travel to Asia indicate the highest income elasticity, which further validate the results obtained through this research (Peng et al. 611-633).

This study reveals that the change in relative price, which is the approximate rate of inflation, has a significant negative impact on the growth in tourist arrivals in the short run. This implies tourists are price sensitive in the short run. However, in the long run the price sensitivity had reduced partly due to the higher income effect than the substitute effect or due to the fact that tourists consider the unique tourism product Sri Lanka offers rather than the associated price or as a combined effect. Therefore, policy makers should control tourism inflation in the short run by either introducing control mechanisms for prices charged from the tourist or improving productivity of the sector since price competitiveness is an influential factor for tourism demand in the short run. In addition, they can evaluate the pricing strategies of competitor countries to develop an effective pricing policy that will enhance competitiveness. However, in the long run price competitiveness will not matter. Hence, sufficient consideration should be given to developing the unique tourism products offered by the country to which tourist will be attracted irrespective of the prices charged. Therefore, policies should be developed to enhance the differentiation of the tourism product offered by Sri Lanka. In this regard, MICE (Meeting, Incentives, Conferences and Events) tourism, agro tourism, village and urban tourism, eco-tourism and medical tourism can be considered as high priority areas with low price elasticities of demand.

It was interesting to observe from this study that the growth rate of tourist arrivals before five months has a significant positive impact on the current growth of the tourist arrivals. As 
revealed by the empirical literature this is known as habit persistency or/and word of mouth effect (Dogru et al. 47-55; Witt and Witt 447-475). When designing tourism policies these effects should be taken into consideration as these are significant in enhancing tourist inflows into Sri Lanka. For instance, habit persistence, in other words repeat tourism, can be enhanced through improving service quality and ensuring that the tourist will have positive experience in all aspects while staying in Sri Lanka. This will in fact create a positive perception about the tourism industry in Sri Lanka, which will enhance word of mouth recommendation. Therefore, apart from commercial advertising, policy makers should develop marketing strategies that focus on improving word of mouth recommendation.

The importance of favourable economic, political and social environment in enhancing the tourist demand for Sri Lankan is further reflected by the positive coefficient obtained for the peace dummy in the long run tourism demand model, which implies that the peaceful environment prevailed in the country after May 2009 had a positive impact on tourist arrivals to the country. Hence, policy makers should be cautious about this and should take necessary action to maintain a favourable economic, political and social environment in the country in order to encourage tourism. 


\section{References}

Abdalla, Suliman Zakaria Suliman. "Modelling Exchange Rate Volatility using GARCH Models: Empirical Evidence from Arab Countries." International Journal of Economics and Finance, vol. 4, no. 3, 2012, pp. 216-229.

Agiomirgianakisa, George, Dimitrios Serenisb and Nicholas Tsounisc. "Effects of Exchange Rate Volatility on Tourist Flows into Iceland." Procedia Economics and Finance, vol. 24 , 2015, pp. $25-34$.

---. "The effects of exchange rate volatility on tourist flows: Evidence from the UK and Sweden."International Journal of Tourism Policy, vol.6, no.1, 2015, pp.1-12.

---. "Exchange Rate Volatility and Tourist Flows into Turkey." Journal of Economic Integration, vol.29, no.4, 2014, pp.700-725.

Akal, Mustafa. "Forecasting Turkey's tourism revenues by ARMAX model." Tourism Management, vol. 25, no. 5, 2004, pp. 565-580.

Aktaş, Ali Rıza and Burhan Özkan. "Exchange Rate Volatility: Effect on Turkish Tourism Incomes." Management Studies, vol 2, no. 8, 2014, pp. 493-499.

Alexander, Carol. Market Risk Analysis, volume 4 -V alue at Risk Models. Vol. 4. Hoboken: John Wiley and sons, 2009.

Ali, Ghulam. "GARCH, GJR-GARCH, TGARCH, AVGARCH, NGARCH, IGARCH and APARCH Models for Pathogens at Marine Recreational Sites ." Journal of Statistical and Econometric Methods, vol. 3, no.2, 2013, pp.57-73.

Al-Najjar, Dana. "Modelling and estimation of volatility using ARCH/GARCH models in Jordan's stock market." Asian Journal of Finance and Accounting 8.1 (2016): 152-167.

Arize, Augustine C, Thomas Osang and Daniel J Slo. "Exchange-Rate Volatility and Foreign Trade: Evidence from Thirteen LDC's." Journal of Business \& Economic Statistics, vol.18, no.1, 2000, pp.10-17.

Australian Bureau of Transport and Communications Economics. The Progress of aviation reform / Bureau of Transport and Communications Economics. Canberra: Australian Govt. Pub. Service, 1993.

Bala , Dahiru A and Joseph O Asemota. "Exchange-Rates Volatility in Nigeria: Application of GARCH Models with Exogenous Break." CBN Journal of Applied Statistics, vol. 4, no.1,2013, pp.89-116. 
Bollerslev, T. "Generalized Autoregressive Conditional Heteroskedasticity." Journal of Econometrics, vol.3, no.3, 1986, pp. 307-327.

Breusch, T S and A R Pagan. "A Simple Test for Heteroskedasticity and Random Coefficient variation." Econometrica, vol.48, 1979 pp.1287-1294.

Brooks, Chris. Introductory Econometrics for Finance. 2. New York: Cambridge University Press, 2008.

Campbell , John Y and Albert S Kyle. "Smart Money, Noise Trading and Stock Price Behaviour." The Review of Economic Studies, vol.60, no.1,1993, pp.1-34.

Central Bank of Sri Lanka . Central Bank of Sri Lanka Annual Report - 2010. Colombo 01: Central Bank of Sri Lanka, 2010.

Central Bank of Sri Lanka. "Annual Report 2015." 2016. 2 November 2016. <http://www.cbsl.gov.lk/pics_n_docs/10_pub/_docs/efr/annual_report/AR201 5/English/9_Chapter_05.pdf $>$.

—. "EXCHANGE RATE." 2006. 21 January 2017. <http://www.cbsl.gov.lk/pics_n_docs/10_pub/_docs/pa/pamphlet/pl_3.pdf>.

Chang, C L and M Mcaleer. "Aggregation, Heterogeneous Autoregression And Volatility Of Daily International Tourist Arrivals And Exchange Rates." Japanese Economic Review, vol. 63,no.3, 2012, pp.397-419.

Chang, Chia-Lin and Michael McAleer. "Daily Tourist Arrivals, Exchange Rates and Volatility for Korea and Taiwan." SSRN Electronic Journa, vol.25, 2009. 13 December 2016. <https://ssrn.com/abstract $=1504651>$.

Cheng, K.M. "Tourism demand in Hong Kong: income, prices, and visa restrictions." Current Issues in Tourism, vol.15,no.3,2012, pp.167-181.

Choudhry, Taufiq. "Exchange rate volatility and the United States exports: evidence from Canada and Japan." Journal of the Japanese and International Economies, vol.9, no.1,2005, pp. 51-71.

Chowdhury, Abdur R. "Does Exchange Rate Volatility Depress Trade Flows? Evidence from Error- Correction Models." The Review of Economics and Statistics, vol.75, no.4, 1993,pp.700-706.

Chu, Fong-Lin. "A piecewise linear approach to modeling and forecasting demand for Macau tourism." Tourism Management, vol.32, no.6, 2011, pp. 1414-1420.

Crouch, Geoffrey I. "Demand elasticities in international marketing: A meta analytical application to tourism." Journal of Business Research,vol. 36, 1996, pp.117-136. 
---. "A meta-analysis of tourism demand." Annals of Tourism Research, vol.22,1995, pp.103-118.

---. "The Study of International Tourism Demand: A Review of Findings." Journal of Travel Research, vol.33, no.1, 1994, pp.12-23.

---. "The Study of International Tourism Demand: A Survey of Practice." Journal of Travel Research, vol.32, no.4, 1994, pp.41-55.

---. "Effect of Income and Price on International Tourism." Annals of Tourism Research, vol.19, no.4, 1992, pp.643-664.

De Vita, Glauco . "The long-run impact of exchange rate regimes on international tourism flows." Tourism Management, vol.45, 2014, pp.226-233.

De Vita, Glauco and Khine S Kyaw . "Role of Exchange rate in Tourism Demand." Annals of Tourism Research, vol.43, 2013, pp.624-627.

Divisekera , Sarath. "A model of international tourism demand." Annals of Tourism Research. vol.30, no.1, 2003, pp.31-49.

Dickey, David A. and Wayne A. Fuller. "Distribution of the Estimators for Autoregressive Time Series With a Unit Root." Journal of the American Statistical Association, vol.74, no.366,1979, pp.427-431.

Dogru, Tarik, Ercan Sirakaya-Turk and Geoffrey I Crouch. "Remodeling international tourism demand: Old theory and new evidence." Tourism Management, vol.60, 2017, pp. 47-55.

Durbin, J and G S Watson. "Testing for Serial Correlation in Least Squares Regression I." Biometrika, vol.37, no.3-4, 1950, pp.409-428.

—. "Testing for Serial Correlation in Least Squares Regression II." Biometrika, vol.38.no.12,1951, pp.159-179.

Dwyer, Larry and Peter Forsyth. "Methods of estimating destination price competitiveness: a case of horses for courses?" Current Issues in Tourism,vol.14, no.8, 2011, pp.751-777.

Ekanayake, E M and Dasha Chatrna. "The effects of exchange rate volatility on Sri lankan exports: an empirical investigation." Journal of International Business and Economy, vol.11, no.1, 2010, pp.51-67.

Enders, W. Applied Econometric Time Series. $3^{\text {rd }}$ ed.. John Wiley and Sons, 2010.

Enders, Walter. Applied Econometric Time Series. $2^{\text {nd }}$ ed. Wiley Series in Probability and statistics, 2004.

Engel, Charles and West D Kenneth . "Exchange Rates and Fundamentals." Journal of Political Economy, vol.113, no.3, 2005, pp.485-517. 
Engle, R and C Granger. "Co-integration and Error Correction: Representation, Estimation and Testing." Econometrica, vol.55, 1987, pp.251-276.

Engle, R F. "Autoregressive Conditional Heteroscedasticity with Estimates of the Variance of UK Inflation." Econometrica,vol.50, 1982, pp.987-1007.

Epaphra, Manamba. "Modeling Exchange Rate Volatility: Application of the GARCH and EGARCH Models." Journal of Mathematical Finance, vol.7, 2017, pp.121-143.

European Commission. europa. 2017. 13 February 2017.

$<$ https://ec.europa.eu/info/business-economy-euro/euro-area/euro/eu-countriesand-euro/ $>$.

Falk, Martin. "The sensitivity of winter tourism to exchange rate changes: Evidence for the Swiss Alps." Tourism and Hospitality Research,vol.13, no.2, 2014, pp.101-112.

Fernando, Sriyantha, et al. "Political violence and volatility in international tourist arrivals: the case of Sri Lanka." Tourism Analysis, vol.8, 2013, pp.575-586.

Garcfa-Ferrer, Antonio and Ricardo Queralt. "A note on forecasting international tourism demand in Spain." International Journal of Forecasting, vol.13, 1997, pp.539-549.

Glosten, Lawrence R, Ravi Jagannathan and David E Ru. "On the Relation between the Expected Value and the Volatility of the Nominal Excess Return on stocks." The Journal of Finance, vol.48, no.5,1993, pp.1779-1801.

Godfrey, L G. "Testing for Multiplicative Heteroscedasticity." Journal of Econometrics,vol.8, 1978, pp.227-236.

Gokovali, Ummuhan, Ozan Bahar and Metin Kozak. "Determinants of length of stay: A practical use of survival analysis." Tourism Management, vol.28, no.3, 2007, pp.736746.

Goldfajn, I and P Gupta. "Does monetary policy stabilize the exchange rate following a currency crisis?" IMF Staff Papers, vol.50, no.1, 2003, pp.90-114.

Goldstein, M and MS Khan. "The Supply And Demand For Exports: A Simultaneous Approach." Review Of Economics \& Statistics, vol.60, no.2, 1978, pp.275-286.

Gonzalez, Pilar and Paz Moral . "An analysis of the international tourism demand in Spain." International Journal of Forecasting, vol.11, 1995, pp.233-251.

Gouveia, Pedro M.D.C.B and Paulo M.M Rodrigues. "Dating and Synchronizing Tourism Growth Cycles." Tourism Economics, vol.11, no.4, 2005, pp.501 - 515.

Gourieroux, Christian and Joann Jasiak. Financial Econometrics:Problems, Models, and Methods. Princeton: Princeton University Press, 2001. 
Gujarati , D N. Basic Econometrics. 4th ed.. New Delhi: Tata McGraw-Hill, 2008.

Investopedia. Bretton Woods Agreement. 2003. 20 February 2017. <http://www.investopedia.com/terms/b/brettonwoodsagreement.asp>.

Jayasekara, S.G.S.D. "Exchange Rate, Exchange Rate Volatility and Foreign Direct Investment in Sri Lanka1." Sri Lanka Journal of Advanced Social Studies,vol.3, no.2, 2013, pp.75-96.

Jarque , Carlos M and Anil K Bera. "Efficient tests for normality, homoscedasticity and serial independence of regression residuals." Economics Letters, vol.6, no.3, 1980, pp.255259.

Johansen, s and K Juselius. "Maximum Likelihood Estimation and Inference on Cointegration - with an Application to the Demand for Money." Oxford Bulletin of Economics and Statistics, vol.52, 1990, pp.169-210.

Karimi, Asrin, Pouya Faroughi and Khalid Abdul Rahim. "Modeling and Forecasting of International Tourism Demand in ASEAN Countries." American Journal of Applied Sciences, vol.12, no.7, 2015, pp.479-486.

Konarasinghe, K.M.U.B. "Forecasting Tourist Arrivals to Sri Lanka:Post-War Period." International Journal of Novel Research in Physics Chemistry \& Mathematics, vol.3, no.1, 2016, pp.57-63.

Kraipornsak, Paitoon. "The world economy, competition, external shocks and demand for international tourist arrivals in Thailand." International Journal of Trade and Global Markets, vol.4, no.1, 2011, pp.93-108.

Lahmiri, Salim . "Modeling and predicting historical volatility in exchange rate market." Physica A, vol.471, 2017, pp.387-395.

Lelwala and L.H.P.Gunaratne. "Modelling Tourism Demand using Cointegrated Analysis: A case study for tourist arriving from United Kingdom to Sri Lanka." Tropical Agricultural Research, vol.20, 2008, pp.50-59.

Li, Gang, Haiyan Song and Stephen F Witt. "Time varying parameter and fixed parameter linear AIDS: An application to tourism demand forecasting." International Journal of Forecasting, vol.22, no.1, 2006, pp.57-71.

Lim, Christine. "The major determinants of Korean outbound travel to Australia." Mathematics and Computers in Simulation, vol.64, 2004, pp.477-485.

--- . "A Meta-Analytic Review of International Tourism Demand." Journal of Travel Research, vol.37, 1999, pp.273-284 . 
Ljung, G and G Box. "On a Measure of Lack of Fit in Time Series Models." Biometrika, vol.66, 1979, pp.265-270.

Lopez, Jose A. "Evaluating the predictive accuracy of volatility models." Journal of Forecasting, vol.20, no.2, 2001, pp.87-109.

MacKinnon, J G. "Numerical distribution functions for unit root and cointegration tests." Journal of Applied Econometrics, vol.11, 1996, pp.601-618.

Marcucci, Juri . "Forecasting Stock Market Volatility with Regime-Switching GARCH Models." Studies in Nonlinear Dynamics \& Econometrics, vol., no.4, 2005, pp. 1-55.

McKenzie, Michael D and Robert D Brooks. "The impact of exchange rate volatility on German-US trade flows." Journal of International Financial Markets, Institutions and Money, vol.7, no.1, 1997, pp.73-87.

Ministry of Economic Development. "Tourism Development Strategy." 2011. SLTDA. 12 December 2016. <http:/ /www.sltda.lk/sites/default/files/English.pdf>.

Murari, Krishna . "Exchange Rate Volatility Estimation Using GARCH Models, with Special Reference to Indian Rupee Against World Currencies." The IUP Journal of Applied Finance, vol.21, no.1, 2015, pp.22- 37.

Mwangi, S.C., O.L.E. Mbatia and J.M. Nzuma. "Effects of exchange rate volatility on french beans exports in Kenya." Journal of Agricultural Economics, Extension and Rural Development,vol.1, no.1, 2014, pp.1-12.

Narayan, Paresh Kumar . "Fiji's Tourism Demand: The ARDL Approach to Cointegration." Tourism Economics, vol.10, no.2, 2004, pp.193 - 206.

Nelson, D B. "Conditional heteroskedasticity in asset returns: a new approach." Econometrica,vol.59, no.2, 1991, pp.347-370.

Onafowora, Olu and Oluwole Owoye. "Exchange rate volatility and export growth in Nigeria." Applied Economics,vol.40, no.12, 2008, pp.1547-1556.

Ozturk, Ilhan . "Exchange Rate Volatility and Trade: A Literature Survey." International Journal of Applied Econometrics and Quantitative Studies,vol.3, no.1, 2006, pp.85-102.

Ozturk, I and H Kalyoncu. "Exchange rate volatility and trade: An empirical investigation from cross-country comparison." African Development Review,vol.21, no.3, 2009, pp.499-513.

Patsouratis, V, Z Frangouli and G Anastasopoulos. "Competition in tourism among the Mediterranean countries." Applied Economics, vol.37, 2005, pp.1865-1870. 
Peace, Ogbeba Ehigocho, Izuchukwu Oji-Okoro and Abba Abubakar Shehu. "Exchange Rate Fluctuation and Tourism Sector Output in Nigeria." International Journal of Management Science and Business Administration vol.3, no.1, 2016, pp.48-55.

Pedroni, P. "Fully modified OLS for heterogeneous cointegrated panels." Advances in econometrics, vol.15, 2001, pp.93-130.

Pelinescu, Elena . "Volatility analysis of the Romanian exchange rate." Procedia Economics and Finance, vol.8, 2014, pp.543 - 549.

Peng, Bo , et al. "A Meta-Analysis of International Tourism Demand Elasticities." Journal of Travel Research,vol.54, no.5, 2015,pp.611-633.

Pesaran, Mohammad Hashem and Bahram Pesaran. Working with Microfit 4.0:Interactive Econometric Analysis. Oxford: Oxford University Press, 1997.

Phillips and Perron. "Testing for a Unit Root in Time Series Regression." Biometrika,vol.75, 1988, pp.335-346.

Pilbeam , Keith and Kjell Noralf Langeland. "Forecasting exchange rate volatility: GARCH models versus implied volatility forecasts." International Economics and Economic Policy,vol.12, no.1, 2015,pp.127-142.

Quantitative Micro Software,LLC. EViews 6 User's Guide. Irvine CA: Quantitative Micro Software,LLC, 2007.

Saayman, Andrea and Melville Saayman. "Exchange Rate Volatility and Tourism -Revisiting the Nature of the Relationship." European Journal of Tourism Research,vol.6, no.2, 2013, pp.104-121.

Santana Gallego, M, F J Ledesma-Rodríguez and J V Pérez-Rodríguez. "Exchange Rate Regimes and Tourism." Tourism Economics,vol.16, no.1, 2010, pp.25-43.

Schiffa, Aaron and Susanne Becken. "Demand elasticity estimates for New Zealand tourism." Tourism Management, vol.32, 2011, pp.564-575.

Sekkat, Khalid and Aristomene Varoudakis . "Exchange rate management and manufactured exports in Sub-Saharan Africa." Journal of Development Economics, vol.62, 2000, pp.237-253.

Selvanathan, S. "The effect of war and other factors on Sri Lankan tourism." Applied Economics Letters, vol.14, no.1, 2007, pp.35-38.

Serenis, Dimitris and Nicholas Tsounis. "The effects of exchange rate volatility on sectoral exports evidence from Sweden, UK, and Germany." International journl of Computational Economics and Econometrics,vol.5, no.1, 2015, pp.71-107. 
Song, Haiyan and Stephen F Witt . Tourism Demand Modeling and Forecasting: Modern Econometric Approaches. $2^{\text {nd }}$ ed.. New York: Routledge, 2011.

Song, Haiyan and Stephen F Witt. "Forecasting international tourist flows to Macau." Tourism Management, vol.27, no.2, 2006, pp.214-224.

Song, Haiyan, et al. "Tourism Demand Modelling and Forecasting: How Should Demand Be Measured?" Tourism Economics,vol.16, no.1, 2010, pp.63-81.

Song, Haiyan, Jae H Kim and Shu Yang. "Confidence Intervals for Tourism demand elsticities." Annals of Tourism Research, vol.37, no.2, 2010, pp.377 - 396.

Song, H and G. Li. "Tourism demand modelling and forecasting-A review of recent research." Tourism Management, vol.29, no.2, 2008, pp.203-220.

Sri Lanka Tourism Development Authority. Annual Statistical Report. Colombo: Sri Lanka Tourism Development Authority, 2014.

Syarifuddin, Ferry, et al. "Monetary Policy Response On Exchange Rate Volatility In Indonesia." Journal of Contemporary Business and Economics Issues, vol.2, 2014, pp.35 54 .

Taylor, S J. (1986) Modelling Financial Time Series. Chichester: John Wiley and Sons Ltd, 1986.

Thompson, Alexi and Henry Thompson. "The exchange rate, euro, switch and tourism revenue in Greece." Tourism Economics, vol.16, no.3, 2010, pp.773-778.

Thorlie, Milton Abdul, Lixin Song and Xiaoguang Wang. "Modelling Exchange Rate Volatility Using Asymmetric GARCH Models (Evidence from Sierra Leone)." International Journal of Science and Research (IJSR),vol.3, no.11, 2014, pp.1206-1214.

Thursby , Jerry G and Marie C Thursby. "Bilateral Trade Flows, the Linder Hypothesis, and Exchange Risk." The Review of Economics and Statistics,vol.69, no.3, 1987, pp.488-495.

Turner, Lindsay W and Stephen F Witt. "Factors Influencing Demand for International Tourism: Tourism Demand Analysis Using Structural Equation Modelling, Revisited." Tourism Economics, vol. 7,no.1, 2001, pp.21-38.

United Nations World Tourism Organization (UNWTO). "International Recommendationsfor Tourism Statistics." 2008. 12 December 2016. <http://unstats.un.org/unsd/publication/SeriesM/seriesm_83rev1e.pdf>.

—. "International Year for Sustainable Tourism for Development 2017 garners support from the sector." 16 December 2016b. 30 January 2017. <http://media.unwto.org/press-release/2016-12-05/international-year-sustainabletourism-development-2017-garners-support-sec $>$. 
—. "UNWTO Tourism Highlights, 2016 Edition." July 2016a. 12 December 2016. <http://www.e-unwto.org/doi/book/10.18111/9789284418145>.

Vieira, Flavio Vilela and Ronald MacDonald. "Exchange rate volatility and exports: a panel data analysis." Journal of Economic Studies, vol.43, no.2, 2016, pp.203-221.

Webber, A.G. "Exchange rate volatility and Cointegration in tourism demand." Journal of Travel Research, vol.39, no.4, 2001, pp.398-405.

Welgamage, Prasanna-Perera Lalith. "Tourism Economics in Sri Lanka: An Econometric Analysis." International Journal of Business and Social Research,vol.5, no.1, 2015, pp.90101.

Witt, Stephen F, Haiyan Song and Stephen Wanhill. "Forecasting Tourism-Generated Employment: The Case of Denmark ." Tourism Economics, vol.10,no.2, 2004, pp.167 - 176.

Witt, S.F and C.A Witt. "Forecasting tourism demand: A review of empirical research." International Journal of Forecasting, vol.11, no.3, 1995, pp.447-475.

Yang, Bill Z. and Tong Zeng. "A Note on the Real Currency Exchange Rate: Definitions and Implications." Journal of International Business and Economics, vol.2, no.4, 2014, pp.45-55.

Yap, Ghialy. "An Examination of the Effects of Exchange Rates on Australia's Inbound Tourism Growth: A Multivariate Conditional Volatility Approach." International Journal of Business Studies, vol.20, no.1, 2012, pp.111-132. 11 November 2016. <http:/ / ro.ecu.edu.au/cgi/viewcontent.cgi?article=1637\&context=ecuworks 2012 $>$. 